Teologia i Moralność, Volumen 15(2020), numer 1(27)

doi: 10.14746/tim.2020.27.1.13

ORCID: 0000-0001-5685-7861

\author{
MONIKA LEWICKA \\ Uniwersytet Kazimierza Wielkiego w Bydgoszczy \\ Wydział Pedagogiki
}

\title{
Przemiany roli ojca we współczesnej kulturze. Implikacje pedagogiczne
}

We obecnych czasach jesteśmy świadkami przemian, które dokonują się w niebywałym tempie i dotyczą niemal wszystkich obszarów ludzkiej egzystencji. Wśród cech współczesności wymienić warto choćby te podstawowe: akcelerację, efektywność, niecierpliwość (nieumiejętność odraczania gratyfikacji, a więc jej natychmiastowość), marność wzorców, roszczeniowość, konsumpcjonizm etc. W tym świecie niezwykle istotne staje się zagadnienie realizacji i przekazu wartości, zwłaszcza w podstawowym środowisku społecznym człowieka, jakim jest rodzina. Mamy bowiem do czynienia z chaosem w systemie wartości, z ich relatywizowaniem czy niekiedy wręcz odrzucaniem i zastępowaniem pseudowartościami.

W sytuacji narastającego zróżnicowania w określaniu rodziny warto przypomnieć, że pojęcie to etymologicznie oznacza rzeczywistość, w której rodzi się człowiek (Wasilewicz 2011, s. 119). Zawarcie związku małżeńskiego wiąże się z podjęciem nowych ról społeczno-małżeńskich, a gdy pojawi się dziecko, również rodzicielskich. Społeczeństwo przekazuje wiele wzorców życia małżeńsko-rodzinnego (również negatywnych), które obecnie ulegają pewnym przeobrażeniom.

Rodzina w czasach współczesnych znajduje się pod wpływem rozległych i diametralnych przemian społeczno-kulturowych, które w istotnym stopniu wpływają na postrzeganie macierzyństwa i ojcostwa. Zachodzące obecnie przemiany ojcostwa są niezwykle istotnym zagadnieniem, gdyż wyobrażenia na temat ojca jako głowy rodziny i oczekiwania, jakie były wobec niego stawiane, uległy istotnym przeobrażeniom. Bezsprzecznie mamy do czynienia z redefinicją jego roli. Coraz częściej również mówi się o kryzysie ojcostwa, 
nieobecnym ojcu lub o nowym ojcostwie. Podejmowanie problematyki ojcostwa jest ważne również z powodu niewielkiej refleksji nad nią w porównaniu chociażby do liczby badań i publikacji dotyczących macierzyństwa. Zauważając, że zmiany społeczno-kulturowe w istotnym stopniu warunkują życie każdego człowieka i niejednokrotnie zmieniają oczekiwania wobec jego zadań, funkcji, warto w tym miejscu postawić sobie pytanie: Jakim przemianom w zakresie ról, funkcji i przypisanych im zadań ulega rola ojca we współczesnej kulturze?

\section{Tradycyjne postrzeganie roli ojca}

W procesie socjalizacji człowiek poznaje swoje role społeczne i uczy się ich. Społeczeństwo ma wobec jednostki określone oczekiwania, które ma do spełnienia, a osobę zajmującą danę pozycję społeczną obowiązuje zespół zachowań (Giddens 2006, s. 51).

Rola w rodzinie definiowana jest natomiast jako ,zestaw istniejących zachowań, jakie członek rodziny odgrywa w relacji z innymi członkami rodziny, włączając w to sposób, w jaki każdy członek rodziny negocjuje z innymi swoje i ich miejsce w ramach danej struktury rodzinnej" (Plopa 2005, s. 19). Jest to więc sposób zachowania i funkcjonowania każdego członka rodziny wobec pozostałych. Istotne jest uświadomienie sobie swojej roli, identyfikacja z nią. Rodzina postrzegana jest wielokrotnie w ujęciu systemowym. W takim jej rozumieniu ważne są zachowania, akceptowanie swoich zadań i roli w niej nie tylko przez matki, dzieci, ale również ojca. Halina Cudak pisze, że „to, jakim kto jest ojcem, zależy w dużej mierze od odczuwania swojej roli rodzicielskiej jako nadrzędnej w stosunku do innych ról pełnionych w życiu, od poczucia niezastąpienia w swym ojcostwie oraz poczucia wspólnego wraz z żoną dbania o los, życie i wychowanie dziecka" (Cudak 1999, s. 65-66). Rola rodzicielska jest zależna również od hierarchii ról i zadań, jakie stawia sobie człowiek. Może być więc tak, że rola rodzicielska jest traktowana priorytetowo, marginesowo lub na równi z pozostałymi rolami (pozarodzinnymi).

W rodzinie tradycyjnej role były sztywno i ściśle określone, przekazywano je z pokolenia na pokolenie w postaci gotowych i niekwestionowanych wzorów zachowań. Funkcje ojcowskie podawane przez nauki empiryczne można sprowadzić do trzech fundamentalnych: prokreacyjnej, wychowawczej i zabezpieczającej. W modelu tradycyjnym kobieta zajmowała się domem i dziećmi, mężczyzna sprawował władzę ekonomiczną i emocjonalną nad członkami rodziny. Był konsekwentny, utrzymywał dyscyplinę wobec dzieci, czyli egzekwował przestrzeganie pewnych zasad. Relacje pomiędzy ojcem a dzieckiem były zdystansowane. Opierały się głównie na wykonywaniu przez dzieci za- 
dań zleconych przez ojca. Wprowadzał je również w świat wartości i norm społecznych. Próba zamiany ról w modelu tradycyjnym była niedopuszczalna. W XIX wieku ojciec postrzegany był przede wszystkim jako moralny nauczyciel. W tym czasie jego zadania koncentrowały się wokół tego, aby dzieci opanowały podstawową wiedzę w zakresie czytania i pisania oraz aby wzrastały i wychowywały się w duchu wartości chrześcijańskich. Wiek XX to kolejny etap w kształtowaniu się roli ojca, którego można określić jako głównego żywiciela rodziny. Relacja pomiędzy ojcem a dzieckiem rozpatrywana była głównie przez pryzmat ekonomiczny. Zadaniem ojca było zapewnienie rodzinie przetrwania (Wróblewska-Skrzek 2017).

Zdaniem Anthony'ego Giddensa, po tym etapie pojawił się „czas nieobecności ojca". Mowa o nieobecności fizycznej (wojna, praca zarobkowa) lub emocjonalnej (ojciec był obecny fizycznie, ale nie brał udziału w wychowaniu). Były to czasy, w których jasno skonkretyzowane były role w rodzinie (męskie i kobiece), ale coraz bardziej traciły one na znaczeniu (Giddens 2006). W modelu patriarchalnym styl ojca był autokratyczny, opierał się głównie na pedagogii zakazów i kar. Charakter stosunków był zatem powierzchowny, instrumentalny i rzeczowy. „Powrót ojca” (choć już w zmienionym kształcie) miał miejsce w latach 70. XX wieku. Dostrzeżono, że również jego rola w życiu i wychowaniu nowo narodzonego człowieka jest nie do przecenienia (Michoń 2016, s. 65). W tym okresie aktywna rola ojca stała się centralnym elementem kształtującym ojcostwo (Wróblewska-Skrzek 2017).

\section{Role społeczne w kontekście przemian społeczno-kulturowych}

Przemiany społeczno-kulturowe nie tylko doprowadziły do zmiany pojmowania rodziny, ale także zmodyfikowały przyjmowane z pokolenia na pokolenie role przypisane kobiecie i mężczyźnie. Początkowo uwaga badaczy skoncentrowana była na kobietach, które ze względu na wysoką aktywność zawodową i łączenie jej z życiem rodzinnym były w trudniejszej sytuacji niż mężczyźni, których to zadania wydawały się stosunkowo proste i przejrzyste. Dopiero pod koniec XX wieku rola kobiet i wzór rodziny skłoniły badaczy do przewartościowania i ponownego zdiagnozowania roli ojca (Wróblewska-Skrzek 2017).

Współcześnie proces przejmowania ról jest zróżnicowany i poddany wieloaspektowości i normatywnemu rozmyciu. Pojawienie się różnorodnych, alternatywnych form życia małżeńsko-rodzinnego ukazało wiele nowych sposobów funkcjonowania związków hetero- i homoseksualnych, powodując tym samym wzrost napięć i konfliktów w procesie przejmowania owych ról. W dzisiejszych czasach obserwujemy raczej proces kreowania roli małżeń- 
sko-rodzicielskiej, a nie tylko jakieś automatyczne przejmowanie jej pokoleniowych wzorców. Postawa taka jest wypadkową dwóch czynników: z jednej strony polega na zdolności odczytania przepisów roli wynikających z oczekiwań danego społeczeństwa, a z drugiej owe role są wyrazem indywidualnych potrzeb partnerów w związku. W przypadku ról małżonków w rodzinie pojawia się wręcz dysonans poznawczy, związany z różnymi oczekiwaniami kobiety i mężczyzny, dotyczący sposobów ich odgrywania i związanych z nimi wymaganiami, które tkwią w wyobrażeniach wyniesionych $\mathrm{z}$ domu rodzinnego, światopoglądu, jak i w oczekiwaniach społecznych (Wasilewicz 2011, s. 103-132).

Paweł Trzos pisze, „iż współcześnie rodzinie coraz częściej przypisuje się jasno konkretne miejsce w sferze publicznej” (Trzos 2014, s. 119). Nie jest ona bowiem tworem hermetycznym, wręcz przeciwnie - podlega różnorodnym wpływom, zmianom i naciskom, które docierają do niej niejako z zewnątrz, z otoczenia społecznego. Wszelkie zmiany (polityczne, społeczne, gospodarcze) w istotnym stopniu dotykają więc rodzinę, krystalizując jej nowe modele, funkcje, a wśród nich również pozycję ojca.

Przemiany społeczno-kulturowe prowadzą także do refleksji nad wartościami i wartościowaniem. Wielokrotnie namysł ten staje się przedmiotem dyskusji i sporów o ich miejsce i udział w odniesieniu do wychowania. Dzieje się tak głównie ze względu na istotę wartości, które określają cele wychowania, wyznaczają zachowanie wychowawcy i wychowanka. Wychowanie w rodzinie niezaprzeczalnie wpisuje się w kluczową problematykę aksjologiczną. Trzeba ją rozpatrywać wielopłaszczyznowo, pewną pomocą może być podejście subdyscyplinarne, a dokładniej spojrzenie z perspektywy pedagogiki rodziny (Opozda 2015, s. 183-184), która podkreśla w sposób jednoznaczny, że potrzebom dziecka najbardziej odpowiada komplementarność miłości matczynej i ojcowskiej. Erich Fromm uważał, że w początkowej fazie rozwoju niemowlę potrzebuje bezwarunkowej miłości matczynej, natomiast po ukończeniu około szóstego roku życia dziecko potrzebuje autorytetu, kierownictwa i miłości ojca. Ojciec kocha dziecko, ponieważ jest ono mu posłuszne i spełnia jego oczekiwania. W ten sposób stymuluje je do przezwyciężania egocentryzmu, zachęca do troski o drugiego człowieka, a więc do przyjmowania właściwych postaw społecznych. Ukazuje dziecku świat prawa, ładu, dyscypliny oraz przygody. Powinien uczyć dziecko, jak kierować życiem, jak radzić sobie z problemami (Fromm 1994, s. 43-45).

Magdalena Zdun pisze, że uwarunkowania współczesności niejako prowokują pytania o jakość kontaktu z ojcem i mobilizują do zdiagnozowania przekazu aksjologicznego w rodzinie. Pojawiają się w tym aspekcie trzy zasadnicze pytania: „co”, ,jak” i „dlaczego” jest przekazywane (Zdun 2012, s. 2). Propozycja Marioli Bieńko dotycząca analizy roli ojca wskazuje, że model 
ojcostwa jest wyznaczony przez zasady i obyczaje panujące w danej kulturze, jak również indywidualne cechy jednostki. Ojcostwo, zdaniem autorki, występuje jako: biologiczne (podstawa pokrewieństwa, kto jest biologicznym ojcem); psychiczne (efekt świadomej pracy ojca nad sobą); wychowawcze (obecność ojca w życiu dziecka i wpływ na jego postawy społeczne); moralne (ojciec jako autorytet); dojrzałe (połączenie dystansu i bliskości) oraz tożsamościowe (ojciec utożsamia się z rolą oczekiwaną przez społeczeństwo) (Bieńko 2008, s. 67).

\section{Postrzeganie ojcostwa we współczesnej kulturze}

Socjologowie jednoznacznie definiują ojcostwo jako rolę społeczną, która rozpatrywana jest w dwóch aspektach. Po pierwsze, możemy mówić o kulturze ojcostwa (culture of fatherhood), rozumiejąc ją jako zespół norm, wartości i oczekiwań wobec mężczyzn, którzy zostają ojcami. Po drugie, mamy praktykę ojcowską (conduct of fatherhood), czyli konkretne, właściwe zachowania mężczyzn będących ojcami wobec kobiety i dziecka. W tradycyjnym społeczeństwie te dwa aspekty były ze sobą zbieżne. Natomiast we współczesnym społeczeństwie szybko zachodzące zmiany kulturowe dotyczące ojcostwa nie zawsze (i nie w tak szybkim tempie - M.L.) przekładane są na konkretne zachowania i działania społeczne ojców. Kultura ojcostwa zmienia się znacznie szybciej niż praktyka. Współcześnie o wiele więcej mówi się o tym, jak powinny wyglądać relacje mężczyzny do swojego dziecka, niż o tym, co de facto rodzic robi w kontekście swoich praktyk rodzicielskich. Brak konsensusu pomiędzy tym, co ojciec powinien robić (według wymagań kulturowych), a tym, co faktycznie robi, będąc ojcem, prowadzi do licznych konsekwencji społecznych, tj. kryzysu ojcostwa, nieobecnego ojca, który pomimo swej obecności fizycznej niejednokrotnie nie jest w stanie sprostać wymaganiom stawianym mu przez społeczeństwo (Wróblewska-Skrzek 2017). Przemiany kulturowe sprawiają, że funkcje rodzicielskie, a także $w$ ich ramach zadania ulegają pewnym zmianom, ale to nie sprawia, że mężczyzna zmienia swoją tożsamość - nie staje się przecież matką. Sposób, w jaki współczesny ojciec odgrywa swoją rolę, zależy od wielu czynników, m.in. sytuacji ekonomicznej, wykształcenia i momentu, w którym został rodzicem.

Tomasz Szlendak wskazuje, że współcześnie rodzinę cechuje „,nowy porządek sentymentalny", nowy wymiar ojcostwa i macierzyństwa, alternatywność jej modeli oraz specyfika kryzysu, co wzmacnia wyalienowanie i osamotnienie dzieci (Szlendak 2011, s. 403-405). Niewątpliwie można mówić o nowym modelu ojcostwa w kontekście szerszych przemian, a więc dotyczących struktury i funkcjonowania rodziny (rodziny pełne, niepełne, zrekon- 
struowane, samotne rodzicielstwo etc.), jak również przemian związanych z kreowaniem ojcostwa (zaangażowane ojcostwo, nieobecne ojcostwo - dop. własny M.L.) (Szyszka 2018, s. 19). Rola mężczyzny w rodzinie, zakres jego obowiązków i zadań w istotnym stopniu związany jest z preferowaną wizją rodziny, która zakłada określony podział ról pomiędzy partnerami.

Można również mówić o swoistej dychotomii, tj. o tradycyjnym modelu ojcostwa, który nadal istnieje, ale jest niejako zastępowany przez nowy model. Współcześnie mamy do czynienia ze ścieraniem się tzw. tradycyjnej i nowej wizji ojcostwa. Tradycyjna wizja ograniczała mężczyznę do żywiciela rodziny, osoby, która odpowiedzialna jest za zaspokojenie materialnych potrzeb żony i dzieci. Taki ojciec rzadko angażował się w kwestie związane $\mathrm{z}$ wychowywaniem dziecka, jeśli już, to przyjmował postawę surowego wychowawcy. „Nowa” wizja ojcostwa niejako zwalnia mężczyznę od bycia surowym, władczym, chłodnym (zimnym) emocjonalnie rodzicem, a proponuje mu rolę zaangażowanego, empatycznego ojca. Współczesny ojciec wielokrotnie angażowany jest $\mathrm{w}$ prace domowe związane $\mathrm{z}$ opieką nad dzieckiem, m.in. bierze czynny udział w wychowaniu go, pomaga w odrabianiu lekcji, towarzyszy w życiu codziennym, wspiera dziecko i stara się rozwiązać jego trudności, spędza z nim wolny czas.

Współczesnemu ojcu nie przypisuje się już stylu autorytatywnego. Coraz częściej przedstawia się go jako stróża wewnętrznej stabilności rodziny. Zmiana nastąpiła w przypadku jego roli - z czysto instrumentalnej na bardziej uczuciową, emocjonalną. Ojciec jest zaangażowany w wychowanie od momentu narodzin dziecka, aż do czasu jego usamodzielnienia się. Zaangażowanie ojców w ten proces rośnie zarówno w sferze społecznej odpowiedzialności, jak i funkcjonalnej dynamiki działań. Opieka przestaje być traktowana jako obciążenie i obowiązek, który spoczywa wyłącznie na matce. Wzrost zaangażowania mężczyzn w opiekę nad dzieckiem ma kilka przyczyn. Pierwszą z nich jest aktywność zawodowa kobiet-matek i spowodowana nią zmiana $\mathrm{w}$ podziale obowiązków domowych i sprawowaniu opieki na dzieckiem. Drugi powód, potwierdzony badaniami naukowymi, wskazuje na prawidłowy rozwój i dobrostan psychiczny dziecka wówczas, gdy ojciec jest zaangażowany w sprawowanie nad nim opieki. I ostatni, trzeci odnoszący się do równości płci, która wydaje się niemożliwa bez relatywnego udziału ojca w sprawowaniu opieki nad potomstwem (Michoń 2016, s. 65).

Rozpatrując współczesne ojcostwo od strony funkcjonalnej, zauważyć możemy istotne zmiany. Bycie ojcem nie sprowadza się obecnie tylko do kilku funkcji, tj. zapewnienia środków do życia czy sprawowania moralnej władzy. Zmianom uległa również funkcja prokreacyjna i wychowawcza. Dojrzała funkcja prokreacyjna wymaga od ojca wypracowania i osiągnięcia właściwej harmonii i relacji między popędliwością a rozumnością. Liczba dzieci i czas 
ich narodzin w małżeństwie nie powinna być bowiem sprawą przypadku, karmiącego się bezrefleksyjnością rodziców w tej ważnej kwestii, lecz działaniem rozumnym i planowym, a przede wszystkim odpowiedzialnym. Dziecko nie jest już traktowane jako kolejna „para rąk do pracy”, ale coraz częściej ujmowane jest w aspekcie emocjonalnym. Funkcja wychowawcza zaś wymaga od ojca dojrzałości osobowej, wewnętrznej spójności i odpowiedzialności wobec zadań małżeńskich, rodzicielskich i edukacyjnych. Funkcja zabezpieczająca w ujęciu tradycyjnym polegała na utrzymaniu i ochronie rodziny przez ojca. Zadanie utrzymania rodziny nie spoczywa dzisiaj już tylko na mężczyźnie, najczęściej oboje małżonkowie pracują zawodowo. Podobnie nowe wyzwania w dzisiejszych czasach niesie ze sobą ojcowska funkcja ochrony rodziny. Do tradycyjnych zadań ochrony żony i dzieci przed agresją zewnętrzną dochodzi bowiem konieczność chronienia ich przed negatywnymi wpływami ze strony współczesnego świata na płaszczyźnie społeczno-duchowej (Wasilewicz 2011, s. 120-121).

W kontekście aspektów i funkcji ojcowskich bezsprzecznie ważne jest odwołanie się do teorii Bowlby'ego, który wskazuje, że relacja przywiązaniowa jest najistotniejszą podstawą zdrowej adaptacji jednostki (zarówno we wczesnym dzieciństwie, okresie dorastania, jak i dorosłości). Pierwszą osobą, wobec której dziecko rozwija przywiązanie, jest matka. Współcześnie jednak coraz większą uwagę poświęca się również nawiązywaniu przez dziecko więzi z innymi osobami sprawującymi opiekę nad nim. Wśród nich szczególna rola przypada właśnie ojcu. Coraz częściej wskazuje się też na to, że role rodziców są komplementarne względem siebie (Czub 2014, s. 74-75). Zaangażowanie ojców w sprawowanie opieki nad dzieckiem, zwłaszcza w początkowych latach jego życia, okazuje się kluczowe dla kształtowania relacji ojciec-dziecko oraz dla prawidłowego rozwoju społeczno-emocjonalnego dziecka (Pleck 2010). Zdaniem T. Szlendaka, zaangażowane ojcostwo wpływa pozytywnie na samopoczucie mężczyzn, a dobre relacje z dziećmi są buforem chroniącym ich przed stresem w pracy zawodowej. Badania wskazują również, że ojcowie niemieszkający ze swoimi dziećmi mają mniejszą ogólną satysfakcję życiową i częściej doświadczają stanów depresyjnych od ojców mieszkających z dziećmi (Kliszek 2019, s. 449-450).

Warto w tym miejscu naszkicować rolę ojca w sytuacji przeobrażeń życia małżeńsko-rodzinnego z uwzględnieniem jego wymiaru aksjologicznego. Paweł Trzos podkreśla, że środowisko rodzinne może okazać się ,aksjologicznie «rodzącym» środowiskiem", albowiem rodzina poprzez intencjonalne oddziaływania swoich członków może implikować próby rewitalizacji wartości, które wcześniej ukonstytuowały „antroposferę aksjologiczną rodziny” (Trzos 2014, s. 125). W procesie wychowania dzieci potrzebują wzorca obojga rodziców. Ojciec również wprowadza dziecko w świat wartości. Wychowanie 
społeczne i religijne w istotnym stopniu zależy od obrazu ojca, od przykładu, jaki daje on swojemu dziecku (Błasiak, Dybowska 2010, s. 109). Niektórzy znawcy problematyki zwracają uwagę na to, że bardziej negatywny wpływ na rozwój dziecka ma brak opiekuńczej postawy u ojca niż sama jego nieobecność. Brak ojca lub posiadanie ojca, który w niewłaściwy sposób spełnia swoje zadania, prowadzi do kreowania w psychice chłopca fałszywego obrazu prawdziwego mężczyzny. Taki wypaczony obraz pełen jest agresji, przemocy i braku szacunku dla innych ludzi. Brak właściwego wzoru ojca może też prowadzić do zakłóceń w prawidłowym wypełnianiu zadań związanych z płcią, w budowaniu właściwych relacji z przyszłą żoną i dziećmi (Wasilewicz 2011, s. 124-127). Ojciec odgrywa oczywiście istotną rolę także w życiu córki. Jest on dla niej pierwszym wzorem mężczyzny. Dlatego poprzez właściwe oddziaływanie powinien pomagać jej w rozwoju kobiecości i gotowości do podjęcia w przyszłości roli żony i matki (Jankowska 2011). Brak ojca lub jego dysfunkcje rodzicielskie mają bardzo negatywny wpływ na życie dziewcząt. Jedną z istotnych trudności, z jakimi spotykają się dziewczęta pozbawione ojcowskiej opieki, jest brak możliwości zaobserwowania u ojców typowych męskich zachowań, co w przyszłości w dużym stopniu utrudnia właściwe rozumienie mężów i synów (Wasilewicz 2011, s. 124). Prawidłowa identyfikacja syna z ojcem determinuje właściwą internalizację norm moralnych. Natomiast przy naruszeniu tychże norm wywołuje u nich poczucie winy (Lacroix 2007, s. 141-146). Zdaniem psychologów, wychowywanie bez ojca ma istotny wpływ na chłopców, którzy w swoim postępowaniu wykazują braki w rozwoju moralnym. Wyjaśniane jest to brakiem męskiego wzorca (Schon 2003, s. 199-120). Ojcem jest się przez całe życie, ojcostwo wraz z rozwojem dziecka powinno ewoluować, zmieniać się, dojrzewać. Nie może pozostać takie samo, bez zmian.

Obecność ojca troszczącego się o dziecko i zaangażowanego emocjonalnie w jego życie jest fundamentem jego właściwego rozwoju, wprowadza do rodziny poczucie bezpieczeństwa i stabilizację. To od ojca chłopiec uczy się męskich zachowań, właściwych relacji do innych ludzi, od niego czerpie wzór bycia mężczyzną. Z kolei brak ojca w znacznym stopniu utrudnia odkrycie i potwierdzenie własnej tożsamości, której młody człowiek będzie w takim wypadku poszukiwał w grupie. Przyjęcie, często bezwolnie, takiej społecznie ,wdrukowanej” tożsamości prowadzi niejednokrotnie do zaprzestania dalszych poszukiwań w tej bardzo ważnej kwestii (Wasilewicz 2011, s. 122-123).

Wydaje się, że dobrym podsumowaniem aspektów i funkcji ojcostwa, które pośrednio łączą się z odgrywanymi współcześnie przez ojca rolami, będzie odwołanie się do scaffoldin, czyli budowania rusztowania. Oznacza ono strategie podejmowane przez dorosłego, które mają na celu pomoc dziecku w sytuacjach, w których bez niej nie dałoby sobie rady. Dotyczą one zarówno 
procesu uczenia się, jak i nabywania kompetencji. Do najistotniejszych zadań realizowanych w scaffoldin jest towarzyszenie dziecku w drodze od regulacji zewnętrznej do samoregulacji. Owo towarzyszenie polega na stopniowym wycofywaniu się ojca z pomocy dziecku przy coraz większej samodzielności dziecka. Przy wspierającym, zachęcającym i wyjaśniającym modelowaniu przed dorosłego dziecko nie tylko uczy się rozwiązywać bieżące trudności, ale nabywa kompetencji do radzenia sobie z podobnymi sytuacjami w przyszłości (Czub 2014, s. 84-85).

Nowe ojcostwo ukształtowane $\mathrm{w}$ ramach kultury ojcostwa nakłada na współczesnego mężczyznę specyficzny zespół norm i oczekiwań. Zdecydowanie zmieniają się oczekiwania wobec współczesnego ojca, co nie przekłada się automatycznie na praktykę ojcowską. Zmienia się jednak świadomość samych mężczyzn, którzy coraz częściej dostrzegają potrzebę zaangażowania się w życie dziecka (Wróblewska-Skrzek 2017).

Zarysowane powyżej współczesne ścieranie się tzw. tradycyjnej i nowej wizji ojcostwa prowadzi oczywiście do kryzysu jego tożsamości, który wpisuje się w szersze zjawisko deficytu tożsamościowej identyfikacji różnych ról, zadań czy postaw społecznych. Jednak właściwe przezwyciężenie owego stanu dokonane na właściwym fundamencie aksjologicznym prowadzić będzie do wszechstronnego rozwoju ojcostwa.

$$
* * *
$$

Świat wartości człowieka rozwija się i realizuje w zależności od wieku, okresu rozwojowego i środowiska życia jednostki (Popielski 2008, s. 161). Pierwszym i naturalnym środowiskiem życia człowieka jest środowisko rodzinne. Rodzina jest miejscem, w którym dziecko gromadzi swoje pierwsze doświadczenia, zdobywa wiedzę o świecie, normach i zasadach postępowania. To środowisko, które w istotny sposób kształtuje aksjologiczny świat dziecka. Potrzeba wychowania ku wartościom jest niezaprzeczalna. Decydują one bowiem o egzystencji człowieka, sensie i jakości jego życia, drodze, którą wybierze, i relacjach interpersonalnych, które będzie nawiązywał i utrzymywał. W procesie wychowania dzieci potrzebują wzorca obojga rodziców.

Rodzina jest podstawową grupą społeczną, w życiu publicznym - poprzez tworzenie strukturalnej jakości - staje się jej instytucją, która ma do spełnienia szereg funkcji (Trzos 2014, s. 121-122). Bycie rodzicem jest nieodwracalne i permanentne, faktu tego nie można już w żaden sposób zmienić, cofnąć, nawet wtedy, gdy osoba nie podejmuje się realizacji roli rodzicielskiej. Roli rodzica nie może ani czasowo, ani na stałe zawiesić. Rodzicem jest się cały czas, bez przerwy (Błasiak, Dybowska 2011, s. 107). Rodzicielstwo ma rów- 
nież charakter społeczny. Szczęśliwa rodzina opiera się na fundamencie właściwych relacji między rodzicami i dziećmi. W relacjach tych rola ojca jest nie do zastąpienia, dlatego w czasach gdy dostrzega się kryzys ojcostwa, ważne jest podkreślanie jego znaczenia i jednoczesne wspieranie działań mających na celu odbudowanie jego autorytetu (Błasiak, Dybowska 2011, s. 128-129). Posiadanie odpowiedniego autorytetu jest konieczne, gdyż w przeciwnym wypadku ojciec nie będzie miał realnego wpływu na rodzinę. Nie może on oczywiście opierać się na lęku czy działaniach represyjnych wobec dzieci czy żony, lecz na fundamentalnym założeniu, że „być ojcem, znaczy oddać się do dyspozycji swoich dzieci” (Augustyn 1999, s. 295).

W badaniach społecznych nad rozwojem dziecka jeszcze do niedawna koncentrowano się głównie na relacjach pomiędzy matką a dzieckiem. Podkreślano, że w zaspokajaniu podstawowych potrzeb dziecka wyjątkowa rola przypada właśnie jej. Zaspokajanie ich tworzy specyficzną i wyjątkową więź pomiędzy matką a dzieckiem (Błasiak, Dybowska 2010, s. 111; Brągiel, Kawula 2007, s. 119-120). W tym tonie umniejszano rolę ojca, traktując go jako mniej znaczącego w wychowywaniu dziecka. W ostatnich latach mamy do czynienia ze sprzecznym wizerunkiem ojcostwa. Z jednej strony w przekazie społecznym (i nie tylko) często wskazuje się na kryzys ojcostwa. Ukazuje się bowiem mężczyzn - ojców niezaangażowanych; tłumacząc ich ,autonomicznością", legitymizuje się lansowany obraz zdystansowania mężczyzn do obowiązków rodzicielskich. Z drugiej jednak strony coraz częściej przedstawiane jest tzw. „nowe” ojcostwo jako zaangażowane, aksjologicznie ugruntowane i silne wspólnotowo (zarówno w fizycznym, czasowym, jak i emocjonalnym kontakcie rodziny).

Warto pamiętać, że - pomimo sprzeczności lansowanego obrazu - społeczny obraz ojcostwa wpisuje się w konieczność zapewnienia dziecku optymalności rozwoju (poznawczego, emocjonalnego, społecznego, aksjologicznego, religijnego etc.), a zmieniające się dynamicznie trendy podkreślają konieczność aktualizacji pola badawczego w tym obszarze teorii i praktyki edukacyjnej. Wydaje się, że w kontekście zachodzących obecnie przeobrażeń życia społecznego będziemy mieli do czynienia z nowym ojcostwem (a nie z jego kryzysem), które będzie (lub już jest) ojcostwem zaangażowanym w rozwój i wychowanie dziecka. Ojcostwem świadomym. 


\section{CHANGING THE ROLE OF THE FATHER IN MODERN CULTURE. PEDAGOGICAL IMPLICATIONS}

\section{SUMMARY}

The aim of the article is to reflect on the changes in the role of the father in the context of socio-cultural changes. The role of the father is associated with specific tasks, norms and expectations that are changing. The article deals with the issue of fatherhood in a traditional approach, to present in this way a contemporary perception of the father's role in child development and the role of functions and tasks related. The issue of modern fatherhood is analysed in terms of committed paternity. The author's attention is also focused on the transmission of value by the father.

Keywords: child; father; fatherhood; parenting; family; education; development; values; transmission of the value

Słowa kluczowe: dziecko; ojciec; ojcostwo; rodzicielstwo; rodzina; wychowanie; edukacja; rozwój; wartości; transmisja wartości

\section{BIBLIOGRAFIA}

Bieńko M. (2008), Model ojcostwa w prywatnym i publicznym kontrakcie społecznym, w: Rodzicielstwo między domem, prawem, stużbami spotecznymi, red. A. Kwak, Warszawa, s. 65-70.

Błasiak A., Dybowska E. red. (2010), Wybrane zagadnienia pedagogiki rodziny, Kraków.

Brągiel J., Kawula S. (2007), Więzi społeczne w rodzinie, w: Pedagogika rodziny. Obszary i panorama problematyki, red. S. Kawula, J. Brągiel, A.W. Janke, Toruń, s. 110-115.

Cudak H. (1999), Znaczenie rodziny w rozwoju i wychowaniu małego dziecka, Warszawa.

Czub M. (2014), Specyfika relacji dziecka z ojcem w pierwszych latach życia z perspektywy teorii przywiazania, w: Dziecko krzywdzone. Teoria, badania, praktyka, t. 13, nr 3, s. 74-85.

Fromm E. (1994), O sztuce miłości, thum. A. Bogdański, Warszawa.

Giddens A. (2006), Socjologia, tłum. A. Szulżycka. Warszawa.

Kliszek E. (2019), Rodzina wobec zagrożeń. Rodzina wobec szans. Socjopedagogika rodziny. Studium rodziny petnej, Warszawa.

Lacroix X. (2007) Naucz mnie żyć. Esej o ojcostwie, Poznań.

Michoń P. (2016), Udziat ojca w czynnościach zwiazanych z opieka nad dzieckiem - międzynarodowa analiza porównawcza, w: Sytuacja rodzin i polityka rodzinna w Polsce po dekadzie członkostwa w Unii Europejskiej, Prace Naukowe Uniwersytetu Ekonomicznego we Wrocławiu, nr 438, Wrocław, s. 64-67.

Opozda D. (2015), Problem wartości i wartościowania $w$ procesie wychowania dziecka $w$ rodzinie - niektóre kwestie w perspektywie metodologicznej, „Paedagogia Christiana” 2/36, s. 183-193.

Pleck J.H. (2010), Paternal involvement: revised conceptualization and theoretical linkages with child out-comes, w: The Role of Father in Child Development, ed. M. Lamb, New York, s. 58-93 .

Plopa M. (2005), Więzi w matżeństwie i rodzinie. Metody badań, Kraków.

Popielski K. (2008), Psychologia egzystencji. Wartości w życiu, Lublin. 
Schon L. (2003), Synowie i ojcowie, Gdańsk.

Szlendak T. (2011), Socjologia rodziny. Ewolucja, historia, zróżnicowanie, Warszawa.

Szyszka M. (2018), Malżeństwo, rodzina, ojcostwo - tendencje przemian, „Roczniki Nauk Społecznych" 10(46), 2(2018), s. 7-27. DOI: 10.18290/rns.2018.46.2-1.

Trzos P.A. (2014), Dziecko w rodzinie jako środowisku spolecznego „stawania się”, „Teologia i Moralność”, 1(15), s. 119-130. DOI: 10.14746/TIM.2014.15.1.8.

Wasilewicz M. (2011), Rola ojca w rodzinie, Laboratorium Wychowania, red. W. Korzeniak, z. 1, Pelplin.

Wróblewska-Skrzek J. (2017), Nowe ojcostwo czy kryzys ojcostwa? Przemiany roli mężczyzny w rodzinie, „Uniwersyteckie Czasopismo Socjologiczne” 18(1), s. 33-40.

Zdun M. (2012), Przekaz aksjologiczny w relacji ojciec-dziecko, „Horyzonty Wychowania” 21, s. $225-242$.

\section{Pozycje internetowe}

Włodarczyk J., Być tatą. Wyniki badań polskich ojców, Fundacja Dzieci Niczyje, s. 94. www. Dzieckokrzywdzone.fdn.pl, [dostęp: 10.12.2019].

Monika Magdalena Lewicka - dr, adiunkt w Katedrze Badań nad Edukacją Estetyczną na Wydziale Pedagogiki Uniwersytetu Kazimierza Wielkiego w Bydgoszczy. Członek Zespołu Pedagogiki Młodzieży przy Komitecie Nauk Pedagogicznych PAN. Zainteresowania naukowe oscylują wokół problematyki rodziny, rodzicielstwa, dziecka i wartości. Autorka artykułów i monografii naukowych poświęconych powyższym zagadnieniom. 